\title{
Virtual milk for modelling and simulation of dairy processes
}

\author{
M. T. Munir, ${ }^{1}$ Y. Zhang, W. Yu, D. I. Wilson, and B. R. Young \\ Chemical and Materials Engineering Department, Industrial Information and Control Centre (I2C2), The University of Auckland, \\ New Zealand 1023
}

\begin{abstract}
The modeling of dairy processing using a generic process simulator suffers from shortcomings, given that many simulators do not contain milk components in their component libraries. Recently, pseudo-milk components for a commercial process simulator were proposed for simulation and the current work extends this pseudo-milk concept by studying the effect of both total milk solids and temperature on key physical properties such as thermal conductivity, density, viscosity, and heat capacity. This paper also uses expanded fluid and power law models to predict milk viscosity over the temperature range from 4 to $75^{\circ} \mathrm{C}$ and develops a succinct regressed model for heat capacity as a function of temperature and fat composition. The pseudomilk was validated by comparing the simulated and actual values of the physical properties of milk. The milk thermal conductivity, density, viscosity, and heat capacity showed differences of less than 2, 4, 3, and $1.5 \%$, respectively, between the simulated results and actual values. This work extends the capabilities of the previously proposed pseudo-milk and of a process simulator to model dairy processes, processing different types of milk (e.g., whole milk, skim milk, and concentrated milk) with different intrinsic compositions, and to predict correct material and energy balances for dairy processes.
\end{abstract}

Key words: process simulation, milk processing, thermal conductivity, viscosity, heat capacity

\section{INTRODUCTION}

Modeling and simulation of industrial processes are useful to predict process behavior and critical for decision making and optimization without putting the real

Received September 26, 2015.

Accepted January 21, 2016.

${ }^{1}$ Corresponding author: tajammal.munir@auckland.ac.nz process at risk. Process simulation significantly contributes to analyzing process operation, performance, and process or product variable trends with reasonably acceptable accuracies (Munir et al., 2012b). Commercial process simulators (such as VMGSim; Virtual Materials Group Inc., Calgary, AB, Canada) are usually preferred over self-developed numerical modeling tools because commercial simulators typically include substantial component libraries, advanced computational methods, comprehensive thermodynamic packages, user-friendly graphical user interfaces (GUI), process flow sheet visualization, and pre-made major unit operations. The simulators have also been validated over many years with large critical user bases (Munir et al., 2013).

Although common in many processing industries, the simulation of dairy processing using commercial process simulators has lagged behind largely because the historical market for most process simulators is chemical or petrochemical applications (Arthur et al., 2014). Other reasons for the slow uptake of process simulation in the dairy industry include the fact that milk is a complex food structure with complex irreversible property changes, multiple phases, and, most importantly, the nonavailability of dairy components in the component libraries of process simulator (Wang and Hirai, 2011; Trystram, 2012; Tajammal Munir et al., 2015). This paper aims to rectify this omission by showing how milk can be considered a mixture of known compounds such that the thermodynamic package of the process simulator can estimate the key physical properties of milk under a variety of processing conditions.

Dairy processing modeling case studies are rare. Tomasula et al. (2013) used SuperPro Designer (Intelligen Inc., Scotch Plains, NJ) to develop a simulation tool for the fluid milk industry, whereas Abakarov and Nuñez (2012) discussed the available food engineering software without actually considering modern process simulator capabilities. Bon et al. (2010) presented the use and capabilities of ProSimPlus (Philadelphia, PA) for milk pasteurization process modeling, and Madoumier et al. (2015) proposed a new modeling approach for liquid foods in a process simulator. 
The key differences between Bon et al. (2010), Madoumier et al. (2015), and the present study are outlined in Table 1. In the present study, milk was considered a "mixture" of water and pseudo-components. Madoumier et al. (2015) followed a similar approach. In contrast, Bon et al. (2010) considered milk as a single pseudo-component but this approach has some drawbacks. For example, such an approach has limited applications when the different components of milk are separated, such as in ultrafiltration, and it is not possible to vary the total solids (TS) such as in powder processes. Finally, we cannot model the influence of different operating conditions on milk mixture components; for example, behavior of milk fat is different from that of milk proteins under the same operating conditions.

There are 2 major differences between Madoumier et al. (2015) and the present study, which are shown in Table 1. The first difference is that milk proteins were modeled differently in the current study and in Madoumier et al. (2015). Madoumier et al. (2015) ignored 20\% (by weight) of the proteins; namely, whey proteins, and considered only casein proteins. However, whey proteins are essential (e.g., for whey milk or "muscle milk"). The influence of heat treatment on both types of milk protein is also different because casein proteins are stable to heat treatment whereas whey proteins are not. Consequently, milk heat treatment processes cannot be modeled without modeling both whey and casein proteins. Furthermore, the denaturation of both proteins is different. The second major difference is that the viscosity of milk with higher TS seems to be an unsolved issue due to non-Newtonian flow behavior in Madoumier et al. (2015). This flow behavior was modeled in the present study.

Process simulation of dairy processing using commercial process simulators involves several specific steps. Regardless of the type of problem and the objective of the simulation, the first basic step is selecting components or mixtures that will be involved in the simulation from the simulator's component library (Luyben, 2002; Seborg et al., 2004; Munir et al., 2012a). Although milk is technically a colloidal suspension, process simulators use the term "mixture" or "pseudo-mixture" in this instance. The main components of milk are water, fats, proteins, lactose, and minerals, all compounds that are uncommon or unavailable in most commercial component libraries.

Primarily, 2 different modeling approaches for milk modeling have been attempted. Ribeiro and Andrade (2003) and Ribeiro and Caño Andrade (2002) used a unique component approach for milk modeling, whereas Zhang et al. (2015) and Tomasula et al. (2014) opted for a pseudo-milk component approach. The unique

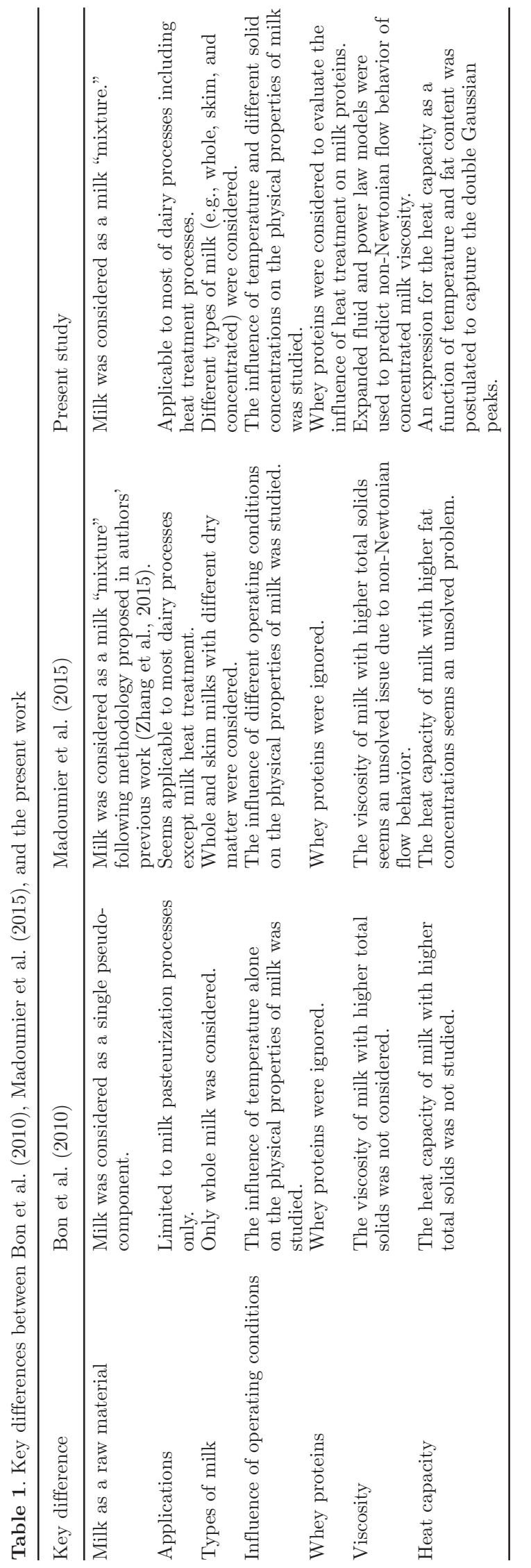

Journal of Dairy Science Vol. 99 No. 5, 2016 
component milk modeling approach is simpler because the milk component properties are specified as constant or depending only on temperature. Such a modeling approach can therefore only be used for situations where composition remains constant or for the simulation of heating or cooling of milk. On the other hand, in the pseudo-milk component approach, the milk components are divided into several pseudo-components: fat, proteins, lactose, and minerals. In this approach, the physical properties of individual pseudo-milk components are modeled and added to compute mixture (i.e., milk) properties. This modeling approach is preferred over the unique component approach because it can be used for unit operations in which composition changes.

The physical properties such as thermal conductivity, density, viscosity, and heat capacity are necessary to predict milk behavior. The physical properties of individual pseudo-milk components can be modeled either by utilizing literature models (e.g., Fernández-Martín, 1972b), or by artificially developing the physical properties of individual pseudo-components (Cheng and Friis, 2007), or by assimilating the physical properties of individual pseudo-components to the properties of a representative component (Zhang et al., 2003, 2015). The literature models as a function of operating parameters (e.g., temperature) are mostly used to give the physical properties of individual pseudo-components. In the absence of literature models, the physical properties of individual pseudo-components are optimized to match the experimentally measured mixture properties, perhaps using a simple trial-and-error strategy. Assimilating the physical properties of individual pseudocomponents to the properties of a representative component is another way to model the physical properties of individual pseudo-components. For example, in nonmilk-related work on vegetable oils, Zhang et al. (2003) represented canola oil by triolein.

In recent work, Zhang et al. (2015) developed a pseudo-milk compound for use within a commercial process simulator. Here, the influence of temperature alone on the physical properties of milk (i.e., thermal conductivity, density, viscosity, and heat capacity) was studied. However, the physical properties of milk are also strongly affected by TS (involving proteins, lactose, fat, and minerals) as well as temperature, and we aimed to address this addition in the current work. The prediction of milk viscosity prediction was another problem in Zhang et al. (2015) that was not addressed.

The amount of milk solids varies along the production line of dairy processing. For example, in the milk powder plant, milk is concentrated from 12 to $13 \%$ (wt/ wt) to 48 to $52 \%$ (wt/wt) TS under vacuum in the evaporator. However, the "pseudo-milk" developed in Zhang et al. (2015) was ineffective at predicting the desired physical properties of milk at higher milk TS. Consequently, in this work, we studied the effect of changing milk TS (i.e., whole milk, skim milk, and concentrated milk) and temperature on key milk physical properties (i.e., thermal conductivity, density, viscosity, and heat capacity) simultaneously.

The key differences between Zhang et al. (2015) and the present study are outlined in Table 2. The properties of pseudo-components were specified differently from previous work. For example, milk fat was considered as a pseudo-component instead of free fatty acids, significantly different molecular weights of fats and proteins were used, milk minerals were considered a pseudo-component, and expanded fluid and power law models were used for the prediction of milk viscosity. Casein and whey proteins were also considered in this study. These alterations were necessary to model the physico-chemical characteristics of real milk constituents. Multiple multivariate models were also used in this study to compare different models.

The creation of an improved pseudo-milk and extension of the already existing pseudo-components in the pseudo-milk mixture will expand the application of process simulators to dairy processes. The creation of an improved pseudo-milk will enable modeling of unit operations such as evaporators and spray driers where milk streams with different TS and temperatures are involved. This work will also enable prediction of the correct material and energy balances around dairy process unit operations.

\section{MATERIALS AND METHODS}

\section{Raw Material (Milk): Composition and Assumptions for Modeling}

Nutritionally, milk is regarded as a complete food given that it contains water, fats, proteins, lactose (carbohydrates), minerals, and vitamins. Normally, milk is divided into 2 components: the milk solids and the aqueous phase. The solid components are dispersed in the aqueous phase. For instance, the gross composition of whole milk ( $13 \%$ by weight total milk solids) is $87 \%$ water, $4 \%$ fats, $3.4 \%$ proteins, $4.8 \%$ lactose, and $0.8 \%$ various minerals as shown in Table 3 . The compositions of other products common in New Zealand (for example) with different TS [e.g., skim, trim (fat-free), and concentrated milk] are also shown in Table 3 . These gross compositions are also relevant elsewhere with minor changes. In this study, whole milk, skim milk, and concentrated milk were considered. Trim milk was ignored as major differences in physical properties are not expected because the milk fat concentration is very small ( $0.3 \%$ by weight) and it is the main cause of 
differences. Creams as separate streams were also not considered explicitly in this study, as extra light (12 to $12.5 \%$ fat) and light (15 to $19.1 \%$ fat; Morison et al., 2012) cream streams are already included as concentrated milk. Heavy creams, those above $40 \%$ fat, were deliberately excluded from consideration in this study due to complex rheological behavior.

In this study, the following assumptions were adopted after the following considerations.

(1) Milk was considered as a homogeneous mixture; it is, in fact, a colloid of water, fats, proteins, lactose, and minerals. Vitamins were not considered in this study as they are soluble in fats and their overall concentration is small.

(2) The chemical formulas of the pseudo-components were not specified. They were considered as inert, because mostly, there is no chemical reaction in milk processing. However, the chemical formulas of the pseudo-components need to be specified in the modeling of cheese making process.

(3) Ordinarily, milk proteins consist of 2 major categories; $\sim 80 \%$ casein proteins and $\sim 20 \%$ whey proteins (by weight). The casein proteins mainly contain phosphorus-containing amino acids. On the other hand, the whey proteins consist of $\beta$-LG ( $>50 \%$ by wt.), $\alpha$-LA ( $>20 \%$ by wt.), and many minor proteins. The whey proteins mainly contain phosphorus-containing amino acids, and are soluble in nature, have a more complex structure, but are a minor component (Bylund, 1995). Only casein and whey proteins were considered in this work because other minor categories of proteins are in smaller quantities.

(4) The aqueous phase of milk was only considered. Milk properties for other phases might not be valid.

(5) The heat capacity of milk for the temperature range 60 to $75^{\circ} \mathrm{C}$ remains constant as most solid milk fats become liquid and there is no latent heat effect (Hu et al., 2009). Heat capacity data in Fernández-Martín (1972a) also validates this assumption.

(6) The heat capacity of milk for the temperature range 4 to $75^{\circ} \mathrm{C}$ was assumed reversible for the simulation purposes because the reversibility of the heat capacity of heated milk is largely unknown. The reversibility can also restore initial heat capacity values.

\section{Process Simulation and Process Simulator Details}

One of the original aims of this work was to establish whether a standard chemical process simulator 
Table 3. Quantitative milk composition (\% by weight); data are from Bylund (1995) and Bon et al. (2010)

\begin{tabular}{lrrrrrr}
\hline & \multicolumn{7}{c}{ Component } \\
\cline { 2 - 7 } Product & Water & Fat & Proteins & Lactose & Minerals & \multirow{2}{*}{ TS } \\
\hline Whole milk & 87.0 & 4.0 & 3.4 & 4.8 & 0.8 & 13.0 \\
Skim milk & 89.3 & 1.7 & 3.5 & 4.7 & 0.8 & 10.7 \\
Trim (fat-free) milk & 90.5 & 0.3 & 3.5 & 4.8 & 0.9 & 9.5 \\
Concentrated milk & 50.0 & 16.0 & 13.0 & 18.0 & 3.0 & 50.0 \\
\hline
\end{tabular}

designed for oil and gas processing was suitable for the simulation of dairy processes. For this study, VMGSim v8.0 (Virtual Materials Group Inc., 2014), was used as the process simulator. As with many similar simulators, except water, all the other components (e.g., fats*, proteins*, lactose*, and minerals*) were not originally available in the component library of the process simulator. Consequently, these components were treated as hypothetical or pseudo-components (denoted by the asterisk, ${ }^{*}$ ) and generated by populating their key basic properties. The classification of the components in a milk mixture used in the process simulator is also shown in Figure 1.

The advanced Peng-Robinson equation of state (EOS) model was selected as the property package for the simulation due to the presence of polar (e.g., water) and hydrocarbon-based (e.g., proteins and fats) compounds in milk (Mühlbauer and Raal, 1995; Díaz et al., 2011; Munir et al., 2012c). Other EOS and activity property packages (e.g., the Wilson activity package) suitable for polar substances were tried but gave poor results compared with the advanced Peng-Robinson thermodynamic model.

\section{Pseudo-Milk Components}

The hypothetical component manager (hypo manager) tool in VMGSim was used to generate milk pseudo-components. Key basic properties such as molecular weight, normal boiling point, and liquid density of pseudo-components were loaded into this tool. These properties can also be fine-tuned as these normally have ranges with minimum and maximum values.

The fine-tuning of the properties can help to best match simulation results with real or literature data. A systematic algorithm for the fine-tuning of the basic properties of the pseudo-components is given in Figure 2. The algorithm started with a manual input of the key basic properties in the hypo manager tool. The model was simulated with water and pseudo-components using these basic properties to predict milk physical properties. The milk physical properties were then compared with real or literature data. This fine-tuning then becomes an optimization problem. The key basic properties were varied in a systematic manner such that the norm of the average relative error (ARE) for the 4 physical properties was minimized. In practice,

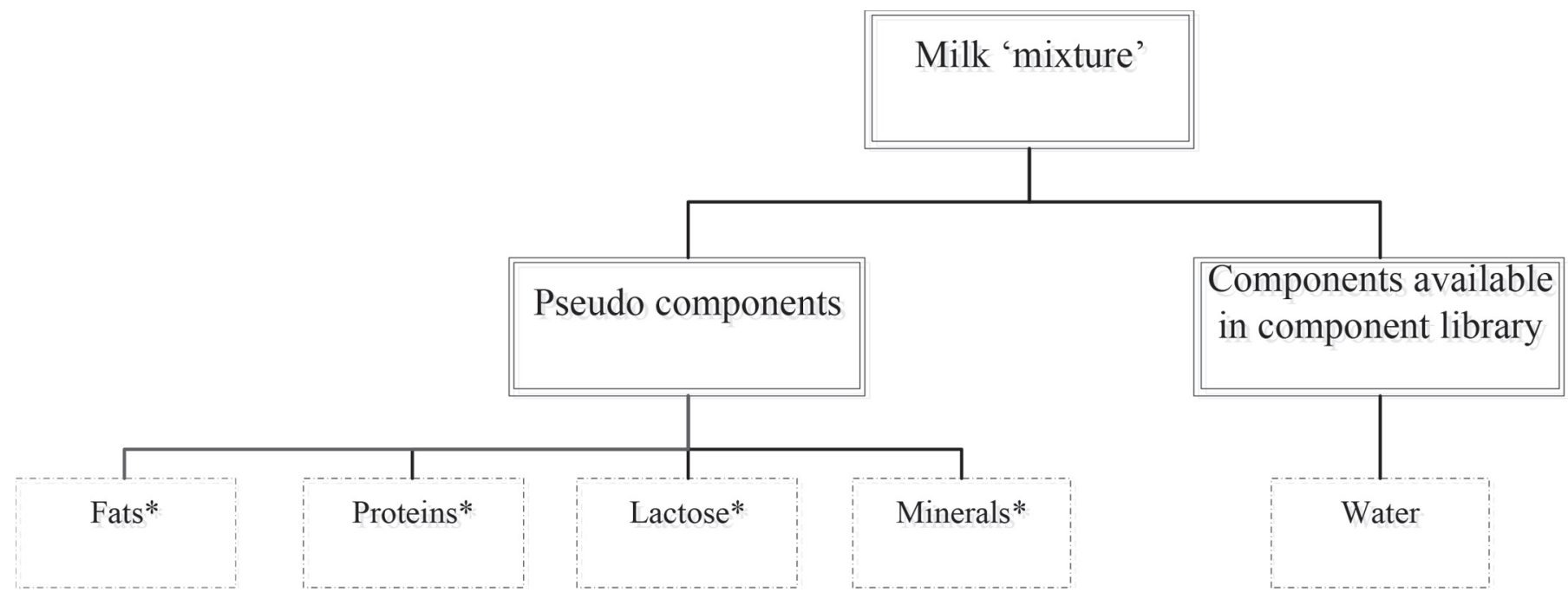

Figure 1. Classification of components in a milk mixture in the simulator ( ${ }^{*}=$ pseudo- or hypothetical components). 
we found that the normal boiling point parameter for milk fat was the most important fitted parameter.

The pseudo-milk components details and their data are given as follows:

- Milk fat*: Milk fat is a complex structure containing around 350 to 437 different types of fatty acids. Three fatty acids in a fat molecule are attached to a backbone mostly made of triglycerides. Milk fat globules (size range: $0.1-17 \mu \mathrm{m}$ ) are in a partially stable emulsion of a milk plasma phase. In this work, the molecular weight of milk fat was set to be $1.355 \mathrm{E} 9 \mathrm{~g} / \mathrm{mol}$, as estimated in Madoumier et al. (2015). Milk fat density was set to be 931 $\mathrm{kg} / \mathrm{m}^{3}$ as given in Fox (2003). Byluppala (2010) also modeled milk fat as a mixture of 12 different fatty acids. However, the milk fat modeling strategy presented in Byluppala (2010) and Zhang

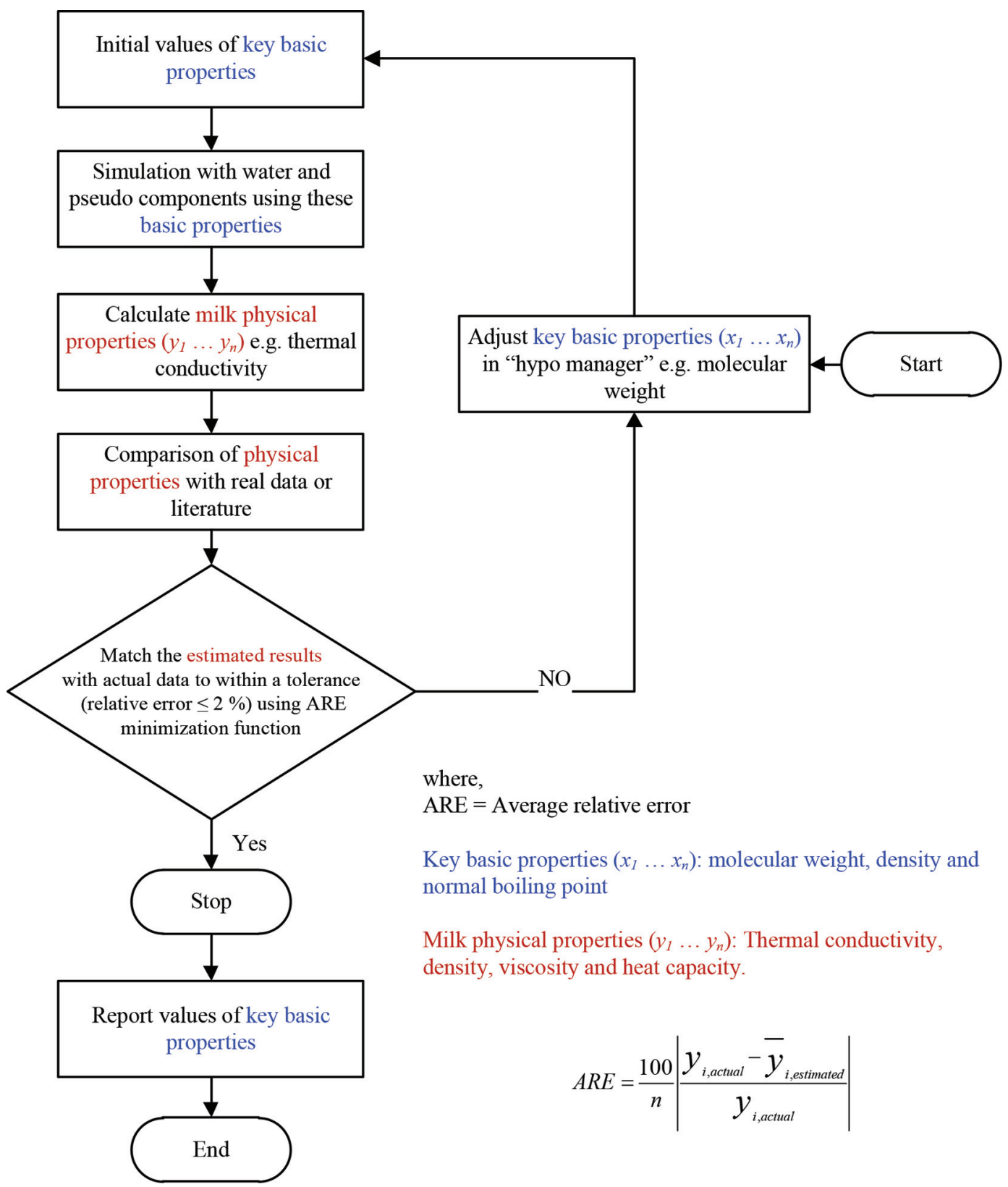

Figure 2. A systematic algorithm for fine-tuning the basic properties of the pseudo-components. Color version available online. 
et al. (2015) was not used in this study because a mixture of different fatty acids is quite different from the actual milk fat structure.

- Milk proteins*: Casein proteins are present in cluster called a casein micelle. In this work, an average molecular weight of casein micelles was set to be around $2.5 \mathrm{E} 8 \mathrm{~g} / \mathrm{mol}$, as estimated in Dewan et al. (1974). The density was set to be 1,250 $\mathrm{kg} / \mathrm{m}^{3}$, similar to our previous work in Zhang et al. (2015). The molecular weight of whey proteins was set to be $\sim 18,400 \mathrm{~g} / \mathrm{mol}$, as reported in Kontopidis et al. (2004).

- Milk lactose*: Lactose is a milk sugar made up of saccharide molecules. Milk lactose was hypothetically generated by setting an average molecular weight to $342 \mathrm{~g} / \mathrm{mol}$, and density around 1,451 $\mathrm{kg} / \mathrm{m}^{3}$ (Zadow, 1984).

- Milk minerals*: Milk is a source of sodium, calcium, phosphorous, zinc, iodine, magnesium, potassium, and other minerals. Milk minerals were represented as a pseudo-component with an estimated average molecular weight according to their weight fractions. In this study, an average molecular weight of milk minerals was set to be around $66 \mathrm{~g} / \mathrm{mol}$ and density around $3,000 \mathrm{~kg} / \mathrm{m}^{3}$ (Jensen, 1995; Gaucheron, 2005).

\section{Milk Viscosity Measurement}

The viscosity measurements were obtained using a rheometer (AR-G2, TA Instruments, Crawley, UK). The viscosity of the milk was measured using the starch cell and conical concentric cylinder geometry. The starch cell held the sample at a specified temperature, and conical cylinder is the geometry used for low-viscosity fluids. The viscosity was measured at increasing shear rates from 1 to $1,000 \mathrm{~s}^{-1}$, with 50 data points in between. These values were chosen to cover a large range of process conditions that the milk would be exposed to, while keeping the temperature constant, and then repeated at different temperatures from $25^{\circ} \mathrm{C}$ to $70^{\circ} \mathrm{C}$ at intervals of $5^{\circ} \mathrm{C}$. Each of the tests was carried out 3 times.

\section{RESULTS AND DISCUSSION}

The milk product streams with different TS (whole milk, skim milk, and concentrated milk) were simulated in the process simulator. Selecting the thermodynamic model, entering process basic information (temperature, pressure, and flow), selecting milk mixture components (i.e., available and pseudo-components), and specifying their compositions were the main steps involved in this simulation.

Sensitivity analysis is a technique that can be used to identify the influence of each physical property model on the overall process simulation model. Recently, Madoumier et al. (2015) used this technique to study the influence of each physical property model on the process simulation of milk. Madoumier et al. (2015) concluded that the process simulation model was most sensitive to any variation in thermal conductivity, followed by density, viscosity, and heat capacity. It is interesting to note that heat capacity has the least effect on the process simulation model. However, in this work, all 4 of these properties in whole milk, skim milk, and concentrated milk were modeled.

The simulation results of the milk physical properties were validated using experimental data or empirical models available in the literature. Table 4 presents a literature review of several empirical models of the milk physical properties reported prominently in the literature. These models are compared over temperature ranges common in a dairy plant such as 4 to $75^{\circ} \mathrm{C}$ for temperature, and TS contents for whole, skim, and concentrated milk.

\section{Milk Thermal Conductivity Results and Validation}

Milk thermal conductivity is a measure of milk's ability to conduct heat. It plays an important role in heat or energy balance calculations in the process simulator. For this reason, careful attention to thermal conductivity modeling is necessary.

The thermal conductivity of different milks with different TS (whole, skim, and concentrated milk) is primarily influenced by temperature (Fox, 2003). Fox (2003) claimed that the thermal conductivity of milk increases linearly with an increase in temperature and decreases with an increase in TS. However, the TS concentration only secondarily affects thermal conductivity. For example, the thermal conductivity of whole and skim milk ranges from 0.530 to 0.613 and 0.527 to $0.622 \mathrm{~W} /(\mathrm{m} \cdot \mathrm{K})$, respectively, over a temperature range of 0 to $100^{\circ} \mathrm{C}$ (Lewis, 1993; McCarthy and Singh, 2009).

The empirical models of Minim et al. (2002), More and Prasad (1988), and Riedel (1949) for thermal conductivity shown in Table 4 were used to validate the simulated thermal conductivity. The experimental data of Minim et al. (2002) was also used for validation, as shown in Figure 3, which shows simulated, empirical model, and experimental results of the thermal conductivity. It also compares different empirical models.

Three clear trends are immediately evident in Figure 3 . The first is that thermal conductivity increases lin- 
Table 4. Existing physical property regression models for milk

\begin{tabular}{|c|c|c|}
\hline Physical property & Regression model & Reference \\
\hline $\begin{array}{l}\text { Thermal conductivity } \\
(\lambda)\end{array}$ & $\begin{array}{l}\lambda=\left(5.9 \times 10^{-1}+1.2 \times 10^{-3} \mathrm{~T}\right)\left(1-7.8 \times 10^{-3} \mathrm{X}\right) \text {, where } T=\text { temperature }\left({ }^{\circ} \mathrm{C}\right), X=\text { TS percentage }, \lambda=\text { thermal } \\
\text { conductivity }(\mathrm{W} / \mathrm{m} \cdot \mathrm{K}) \text {, also denoted by } k \text {. } \\
\lambda=\left(326.58+1.0412 T-3.37 \times 10^{-3} T^{2}\right)\left(4.6 \times 10^{-1}+5.4 \times 10^{-1} X_{\text {Water }}\right) 1.73 \times 10^{-3} \text {, where } X_{\text {Water }}=\text { water fraction } \\
\text { (and other terms are as previously defined). } \\
\lambda=1.63 \times 10^{-2}+1.4 \times 10^{-3} \mathrm{~T}+0.2 X_{\text {Water }}+4 \times 10^{-2} X_{F a t} \\
\lambda=5.28 \times 10^{-1}+2.13 \times 10^{-3} \mathrm{~T}-7.32 \times 10^{-6} T^{2}\left(1-X_{F a t} 0.843+1.9 \times 10^{-3} \mathrm{~T}\right) \text {, where } X_{F a t}=\text { fat fraction } \\
\text { (and other terms are as previously defined). }\end{array}$ & $\begin{array}{l}\text { More and Prasad } \\
(1988) \\
\text { Riedel (1949) } \\
\text { Minim et al. (2002) } \\
\text { (using regression } \\
\text { modeling) }\end{array}$ \\
\hline Density $(\rho)$ & $\begin{array}{l}\rho=\left(1,040.7-2.665 \times 10^{-1} T-2.3 \times 10^{-3} T^{2}\right)-\left[X_{F a t}\left(1.011+9.76 \times 10^{-3} T-4.81 \times 10^{-5} T^{2}\right)\right] \text {, where } \rho=\operatorname{density~}\left(\mathrm{kg} / \mathrm{m}^{3}\right) \\
\text { (and other terms are as previously defined). } \\
\rho=1,042.01-0.37 T+3.6 \times 10^{-4} T^{2} \\
\rho=\frac{1}{\Sigma_{w, i}^{X} / \rho_{i}} \text {, where } \rho_{\text {Fat }}=925.56-4.1757 \times 10^{-1} T, \rho_{\text {Proteins }}=1,329.9-5.1840 \times 10^{-1} T, \rho_{\text {Lactose }}=1,599.1-3.1046 \times 10^{-1} T \text {, } \\
\rho_{\text {Minerals }}=2,423.8-2.8063 \times 10^{-1} T \text {, where } X=\text { component mass fraction, } w, i=\text { weight fraction of component } i \text { (and } \\
\text { other terms are as previously defined). }\end{array}$ & $\begin{array}{l}\text { Minim et al. (2002) } \\
\text { Choi and Okos (1986) }\end{array}$ \\
\hline Viscosity $(\mu)$ & $\begin{array}{l}\mu=\left(0.9565-1.3004 \times 10^{-3} T+1.9580 \times 10^{-4} T^{2}\right)+X_{\text {Fat }}\left(0.4766-1.144 \times 10^{-2} T+7.2642 \times 10^{-5} T^{2}\right), \text { where } \mu= \\
\text { viscosity }(\mathrm{cP}) \\
\log \mu=A_{0}+A_{1} T+A_{2} T^{2}+\left(B_{0}+B_{1} T+B_{2} T^{2}\right) S+\left(C_{0}+C_{1} T+C_{2} T^{2}\right) S^{2}, \text { where } S=\text { total solids content }(\% \text { in mass }) \text {, } \\
\text { and } A_{i}, B_{i} \text {, and } C_{i} \text { are dimensionless coefficients (and other terms are as previously defined). } \\
\mu=1,000 \mu_{\text {Water }} \exp \left(\sum A_{i} X_{i} / X_{\text {Water }}\right) \text {, where } A_{\text {Fat }}=3.46-0.025 T+1.6 \times 10^{-4} T^{2}, A_{\text {Proteins }}=15.367-0.175 T+0.0017 T^{2}, \\
\text { and } A_{\text {Lactose }}=3.35-2.38 \times 10^{-2} T+1.25 \times 10^{-4} T^{2} \text {. }\end{array}$ & $\begin{array}{l}\text { Kessler (2002) } \\
\text { Fernández-Martín (1972b) } \\
\text { Morison et al. (2012) }\end{array}$ \\
\hline Heat capacity $\left(C_{p}\right)$ & $\begin{array}{l}C_{p}=3,744.48+1.15 T+3.93 \times 10^{-3} T^{2} \\
C_{p}=\sum C_{p_{i}} X_{i}, \text { where } C_{p_{F a t}}=1.984+1.473 \times 10^{-3} T-4.8008 \times 10^{-6} T^{2}, C_{p_{\text {Proteins }}}=2.008+1.2089 \times 10^{-3} \mathrm{~T}-1.3129 \times 10^{-6} T^{2}, \\
C_{p_{\text {Lactose }}}=1.5488+1.9625 \times 10^{-3} \mathrm{~T}-5.9399 \times 10^{-6} T^{2}, C_{p_{\text {Minerals }}}=1.0926+1.8896 \times 10^{-3} \mathrm{~T}-3.6817 \times 10^{-6} \mathrm{~T}^{2}, \text { and } \\
C_{p}=1.4017+1.1 \times 10^{-3} \mathrm{~T}+1.18 X_{\text {Water }}+4.33 \times 10^{-2} X_{\text {Fat }} \text {, where } C_{p}=\text { heat capacity }(\mathrm{J} / \mathrm{g} \text { per } \mathrm{K}) \text { (and other terms } \\
\text { are as previously defined). }\end{array}$ & $\begin{array}{l}\text { Minim et al. (2002), } \\
\text { and Hu et al. }(2009) \\
\text { Choi and Okos (1986) }\end{array}$ \\
\hline
\end{tabular}


early with an increase in temperature. This observation agrees with Fox (2003), as noted above. The second obvious trend is that, for whole and skim milk, simulated conductivity, empirical models, and experimental data were mutually consistent (relative error $\leq 2 \%$ ). However, the model of Riedel (1949) showed the closest match to the simulated conductivity (relative error $\leq 0.7 \%$ ). The third trend was that for concentrated milk, the models of Minim et al. (2002) and More and Prasad (1988) appear different (relative errors $\leq 14 \%$ and $\leq 31 \%$, respectively) from the model of Riedel (1949) and simulated conductivity. However, the discrepancy
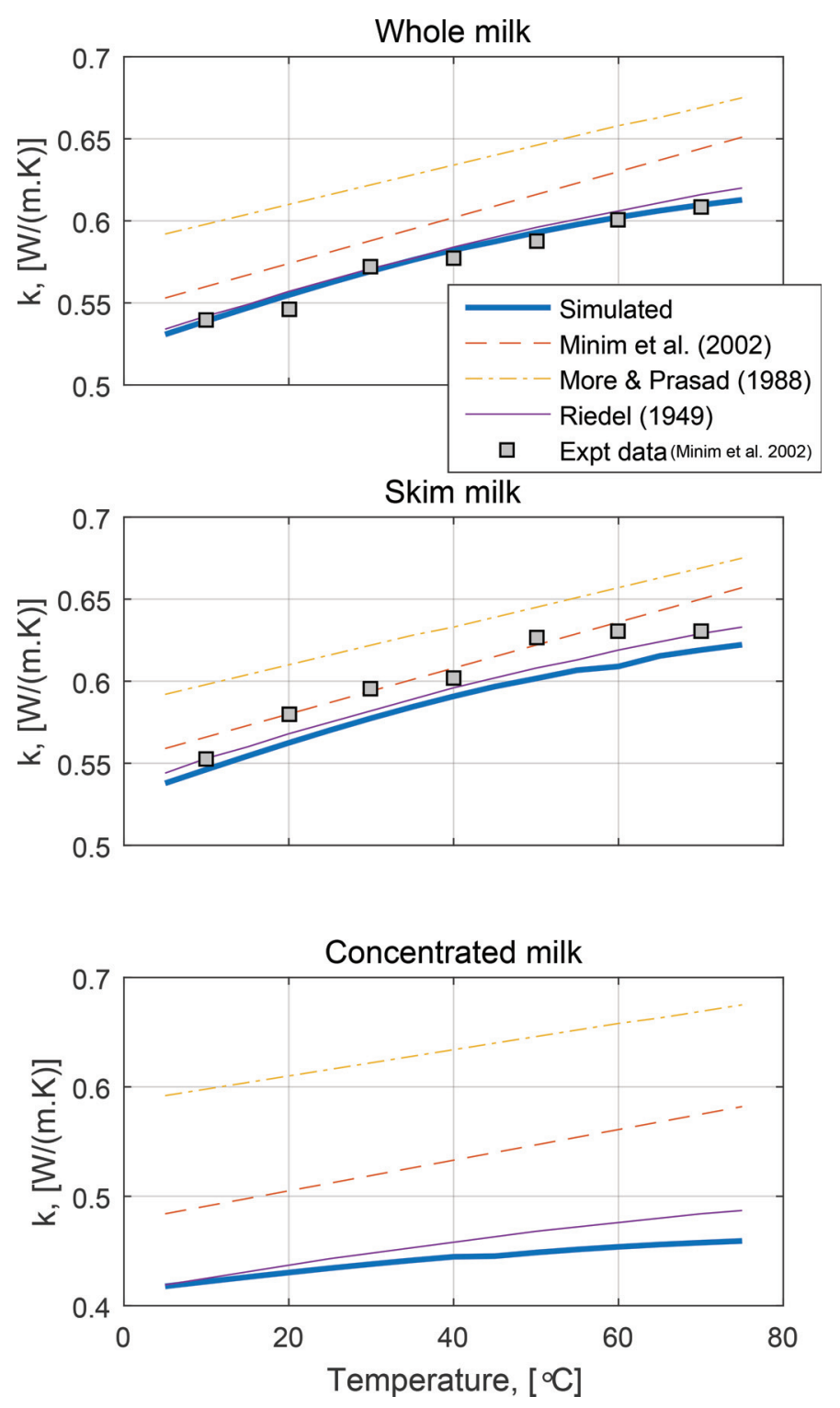

Figure 3. Simulation of the thermal conductivity $[k, \mathrm{~W} /(\mathrm{m} \cdot \mathrm{K})]$ of whole, skim, and concentrated milk over a range of temperatures. Expt = experimental. Color version available online. between simulated thermal conductivity and Minim et al. (2002) was smaller (relative error $\leq 1 \%$ ). These discrepancies may be explained by the fact that Minim et al. (2002) used a higher ratio of fat to other TS (i.e., TS other than fat), and More and Prasad (1988) calculated thermal conductivity for uncommon temperature $\left(40-90^{\circ} \mathrm{C}\right)$ and TS (37-73\% wt.) ranges. The model of Riedel (1949) also showed the closest match (relative error $\leq 0.5 \%$ ) to the simulated thermal conductivity for concentrated milk. For this reason, the model of Riedel (1949) is the best choice for milk thermal conductivity followed by the model of Minim et al. (2002). However, valid experimental data for concentrated milk thermal conductivity was not available to further validate it.

The models of Minim et al. (2002) and Riedel (1949) for thermal conductivity of most milk streams with different TS emerged as the most relevant empirical models. These models for thermal conductivity and perhaps, more importantly, the reported experimental data of Minim et al. (2002) validated the simulated thermal conductivity results. However, for concentrated milk process simulation, careful attention to the energy balance calculation might be necessary as the simulated thermal conductivity results can only be compared with empirical model results in this case.

\section{Milk Density Results and Validation}

The density of milk depends on temperature and composition (i.e., fat, water, proteins, lactose, and minerals densities) and their mass fractions. It is interesting to note that the fat component of milk (density $\approx 931$ $\mathrm{kg} / \mathrm{m}^{3}$ ) with the lowest density among the components (water $\approx 999 \mathrm{~kg} / \mathrm{m}^{3}$, proteins $\approx 1,250 \mathrm{~kg} / \mathrm{m}^{3}$, lactose $\approx 1,451 \mathrm{~kg} / \mathrm{m}^{3}$, and minerals $\approx 3,000 \mathrm{~kg} / \mathrm{m}^{3}$ ) is mainly responsible for the complicated influence of temperature and composition on milk density. This influence of fat is complicated by the fact that the density of the milk fat depends on the ratio of liquid fat (with lower density) to solid fat (with higher density) within the milk fat melting point range $\left(-35^{\circ} \mathrm{C}\right.$ to $\left.40^{\circ} \mathrm{C}\right)$. Above $40^{\circ} \mathrm{C}$, almost all milk fat becomes liquid, with a lower density (McCarthy and Singh, 2009).

The density of milk can be determined using different methods, such as hydrometry (Bradley, 2010), hydrostatic balance (Al-Nabulsi et al., 2011), and dilatometric analysis (Kumar et al., 2010). Furthermore, the empirical models of Kessler (2002), Minim et al. (2002), and Choi and Okos (1986) for prediction of milk density are available in the literature.

In this work, the simulated milk with different TS (whole, skim, and concentrated) densities were compared with real milk literature data. The empirical 

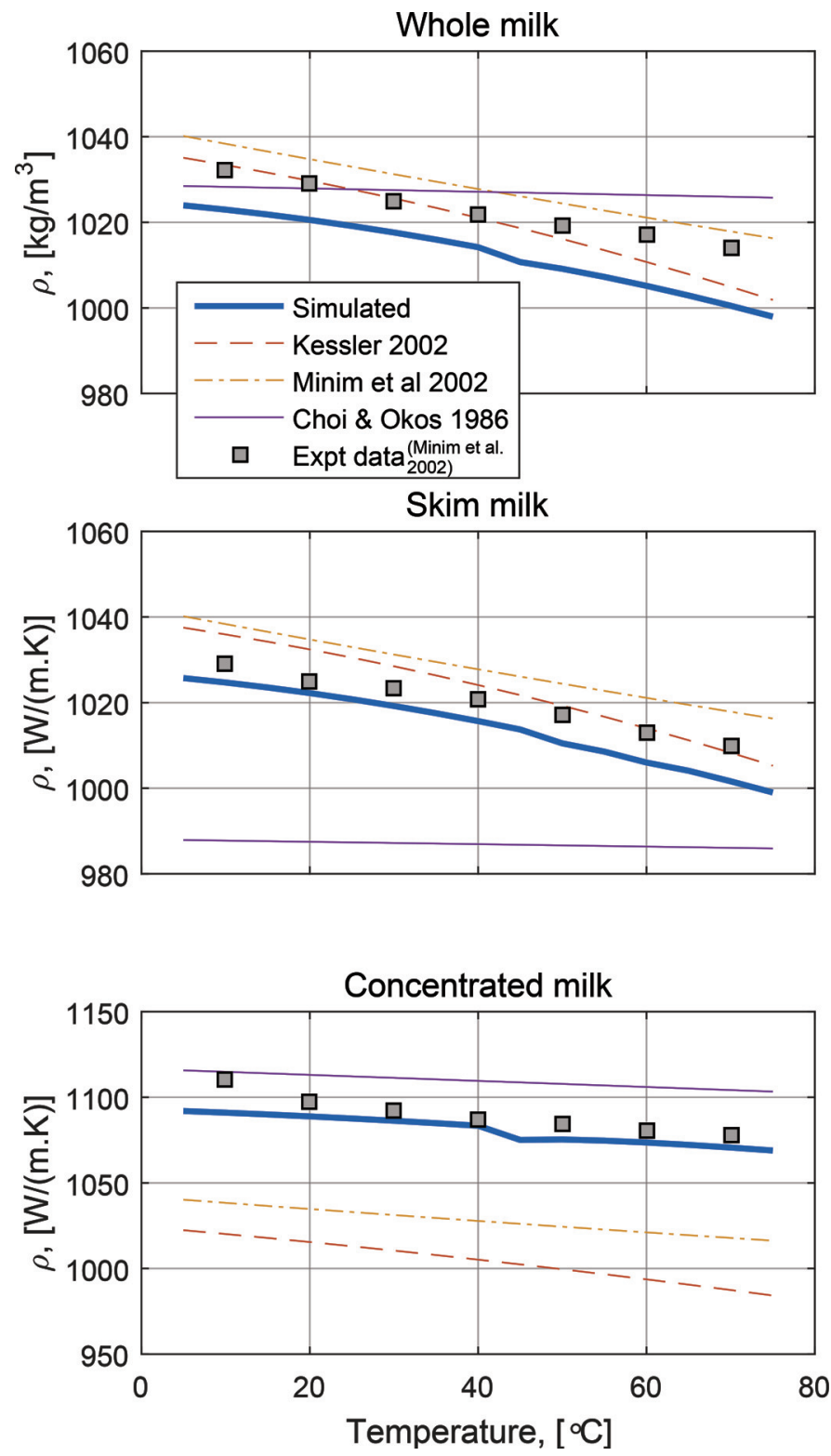

Figure 4. Simulated, model, and experimental (Expt) density $(\rho$, $\mathrm{kg} / \mathrm{m}^{3}$ ) of whole, skim, and concentrated milk over a range of temperatures. Color version available online.

models of Kessler (2002), Minim et al. (2002), and Choi and Okos (1986), shown in Table 4, were used in this work to predict the actual density of whole, skim, and concentrated milk over the temperature range 4 to $75^{\circ} \mathrm{C}$. Similarly, another empirical model of milk density and experimental data were reported in FernándezMartín (1972b). McCarthy and Singh (2009) discussed and elaborated upon the advantages of the FernándezMartín (1972b) empirical model over other milk density empirical models available in the literature. However, the experimental data of Minim et al. (2002) was used for validation, as shown in Figure 4. Fernández-Martín (1972b)'s empirical model and experimental data were not used in this study because it had a similar methodology and same fat-to-nonfat solids ratio to that in Minim et al. (2002).

The simulated, empirical model, and experimental results of the whole, skim, and concentrated milk densities are graphically presented in Figure 4, which shows that milk density linearly decreases with an increase in temperature. This trend is in conformity with reports by Kessler (2002), Minim et al. (2002), Solanki and Rizvi (2001), Choi and Okos (1986), and FernándezMartín (1972b). An increase in milk density with an increase in TS is also evident in Figure 4. Note that the density of concentrated milk is higher than that of whole or skim milk.

For the whole and skim milks, the simulated density, Kessler (2002) and Minim et al. (2002) empirical models, and experimental data were mutually consistent (relative error $\leq 2 \%$ ). However, for the concentrated milk only, Minim et al. (2002)'s empirical model and experimental data were in relatively good agreement with simulated density (relative error $\leq 4 \%$ ). Choi and Okos (1986)'s empirical model does not consider the effect of TS on milk density. This seems to be a major reason for the discrepancy between the simulated and Choi and Okos (1986) milk densities (relative error $\leq 8 \%$ ). Furthermore, the empirical model of Kessler (2002) was quite different for concentrated milk.

\section{Milk Viscosity Results and Validation}

Milk viscosity is an important parameter in the production of milk powder. The viscosity of milk concentrate has a considerable effect on the performance of milk concentrating unit operations, maintenance, and product quality. The viscosity and flow behavior of milk also varies with temperature and TS concentration. For these reasons, accurate modeling of milk viscosity is necessary to model unit operations such as the evaporator and the drier, where temperature and TS change during processing.

The viscosities of whole, skim, and concentrated milk were simulated and compared with the empirical models of Morison et al. (2012), Kessler (2002), and Fernández-Martín (1972b) for milk viscosity, as shown in Figure 5. The simulated results were also compared with experimentally measured viscosities (explained in the Milk Viscosity Measurement section). In this study, a rheometer was used for the viscosity measurement over the temperature range 25 to $70^{\circ} \mathrm{C}$. These results are consistent with those reported by Souza (2011), with a relative error $\leq 0.4 \%$ for of milk viscosity. 
Four observations in Figure 5 are evident. The first is that the viscosity of the milk decreases with an increase in temperature. This is because the ratio of liquid milk fat to solid milk fat increases with increase in temperature, causing a decrease in milk viscosity. The second observation is that a bump in the simulated viscosity above $40^{\circ} \mathrm{C}$ is evident. This is because all solid fat becomes liquid above $40^{\circ} \mathrm{C}$ (McCarthy and Singh, 2009). The third observation is that the simulated milk viscosities, empirical model of Fernández-Martín (1972b), and experimental data were mutually consistent (relative error $\leq 2.5 \%$ ), especially above $25^{\circ} \mathrm{C}$.
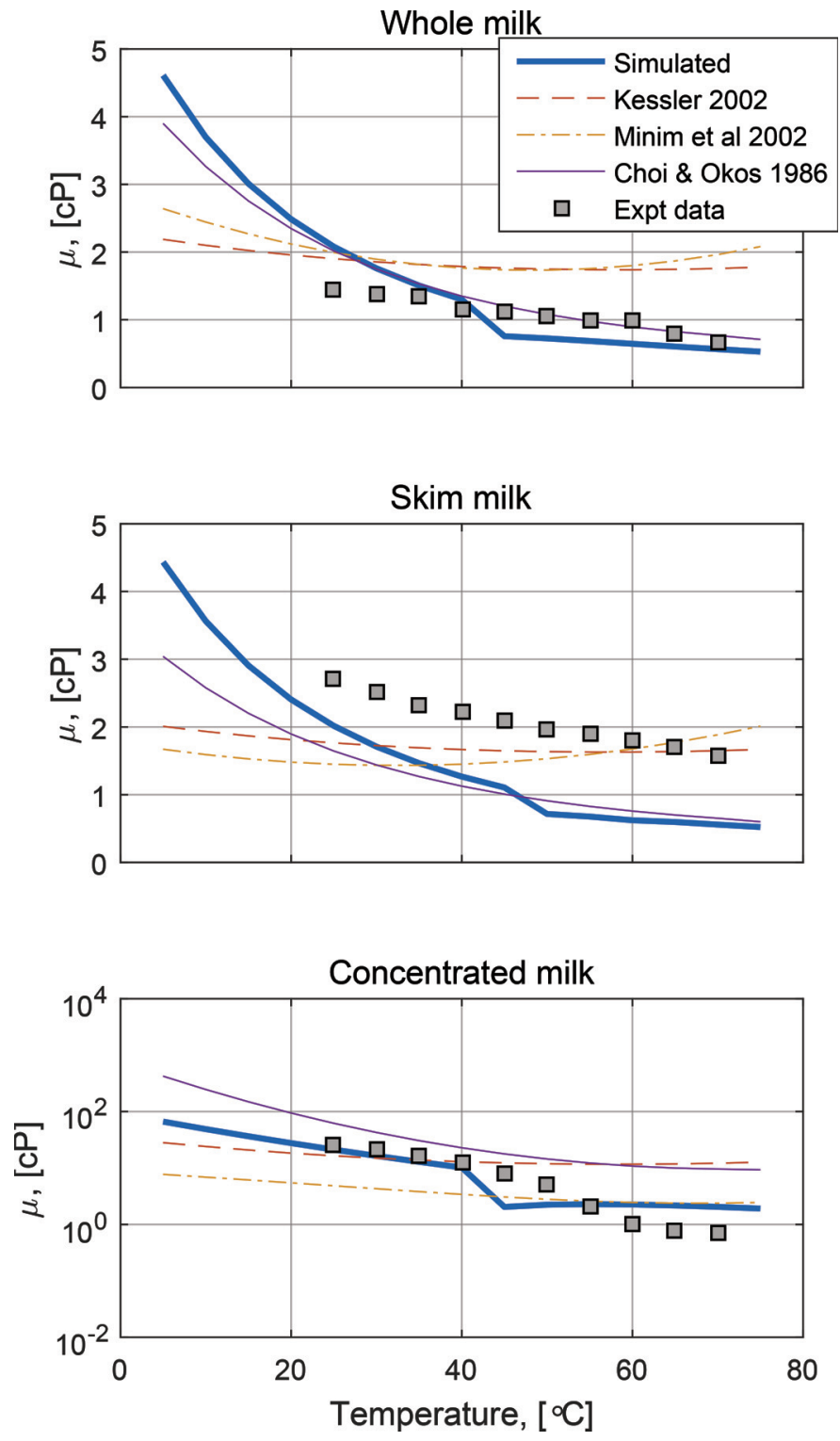

Figure 5. Simulated, model, and experimental (Expt) viscosity ( $\mu$, $\mathrm{cP}$ ) of whole, skim, and concentrated milk over a range of temperatures. Color version available online.
The fourth observation is that the empirical model of Kessler (2002) was quite different from the simulated and experimental viscosities of skim and concentrated milks (relative error $\geq 25 \%$ ). The empirical model of Morison et al. (2012) was slightly better as it considers the non-Newtonian behavior of concentrated milk (relative error $\leq 20 \%$ ). The non-Newtonian behavior of concentrated milk has been reported by several other authors; for example, Vélez-Ruiz and Barbosa-Cánovas (1998) and Wang and Hirai (2011).

The empirical model of Fernández-Martín (1972b) predicted significantly higher viscosity values for concentrated milk below $25^{\circ} \mathrm{C}$. This discrepancy is because Fernández-Martín (1972b) used a general equation for 10 different types of milk, kinematic viscosity coefficients were used, and the coefficients were calculated by the least squares error method. These might explain the significantly higher predicted viscosity values at lower temperature. In addition, the viscosity of nonNewtonian fluids depends on many parameters such as operating conditions, equipment, and shear rate. These parameters might also be responsible for significantly higher predicted viscosity values at lower temperatures in Fernández-Martín (1972b). It is evident in Figure 5 that the experimental values of concentrated milk viscosity are much lower than viscosity values predicted by the empirical model of Fernández-Martín (1972b).

Milk viscosity prediction was an unresolved issue in Madoumier et al. (2015) and Zhang et al. (2015). This was due to complex non-Newtonian behavior of milk. In the current study, we used expanded fluid-based viscosity correlation and power law models to model the nonNewtonian behavior of the concentrated milk. Recently, Yarranton and Satyro (2009) used an expanded fluidbased viscosity correlation to model the non-Newtonian behavior of heavy hydrocarbons in VMGSim. The same methodology was used in this work.

\section{Milk Heat Capacity Results and Validation}

Heat capacity measures the specific amount of heat required to raise the temperature of milk and, therefore, is key in modeling, for example, the economics of a dairy plant. The measured heat capacity of the complex compound milk includes both latent and sensible heats, and is, therefore, termed "apparent heat capacity." Furthermore, milk is a mixture of substances with different melting points, and apparent heat must be added or removed to bring about changes in temperature during heating or cooling.

Like thermal conductivity, viscosity, and density, the heat capacity of milk is a function of temperature and TS concentration, although, unlike the other physical properties, it is considerably more complex and non- 


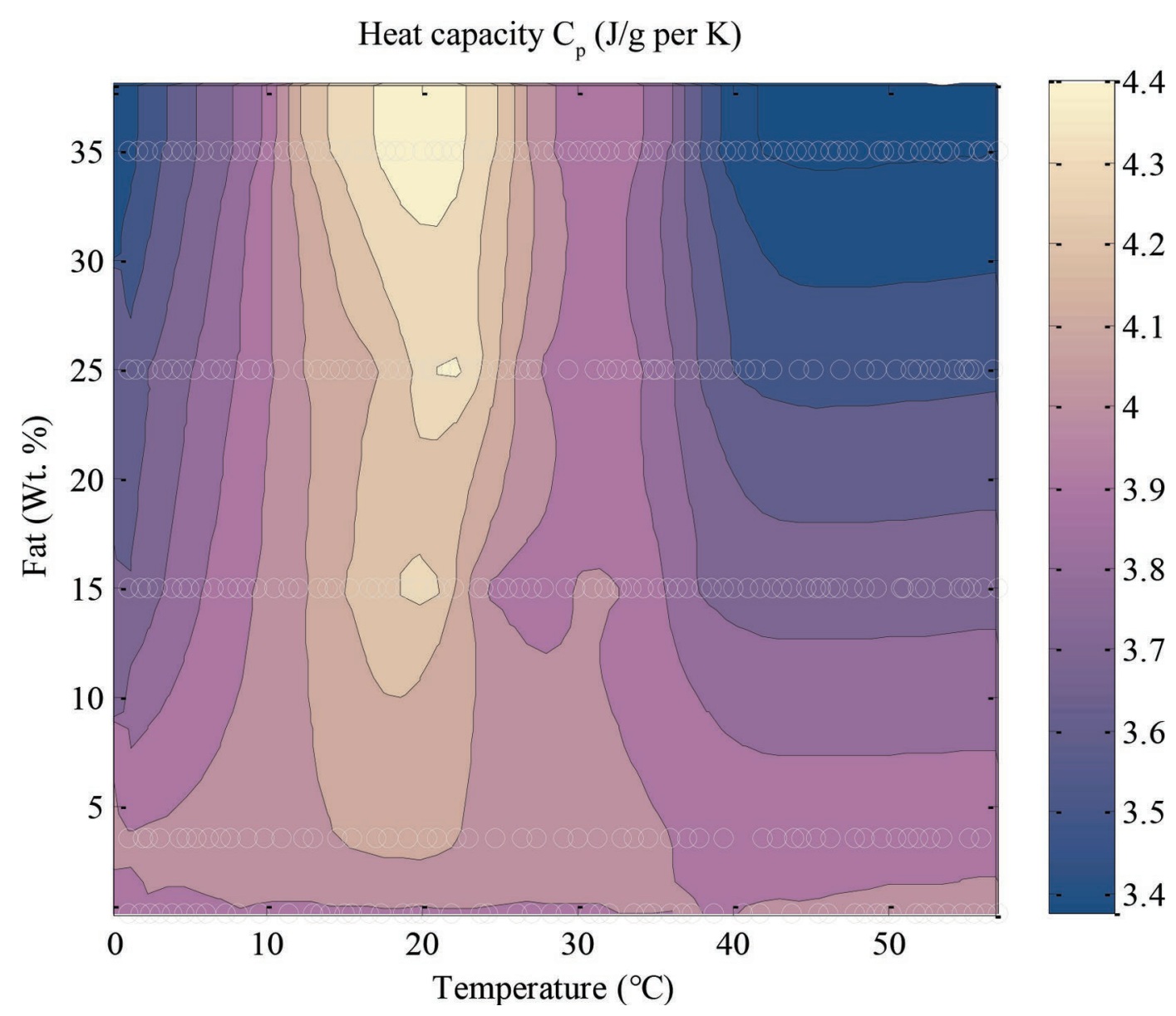

Figure 6. The apparent heat capacity $\left(C_{p} ; \mathrm{J} / \mathrm{g}\right.$ per $\left.\mathrm{K}\right)$ of milk at different fat contents over the temperature range of 0 to $60^{\circ} \mathrm{C}($ data adapted from $\mathrm{Hu}$ et al., 2009). Note that circles show different fat concentrations (e.g., 0.1, 3.5, 15, 25, and 35 wt. \%). Color version available online.

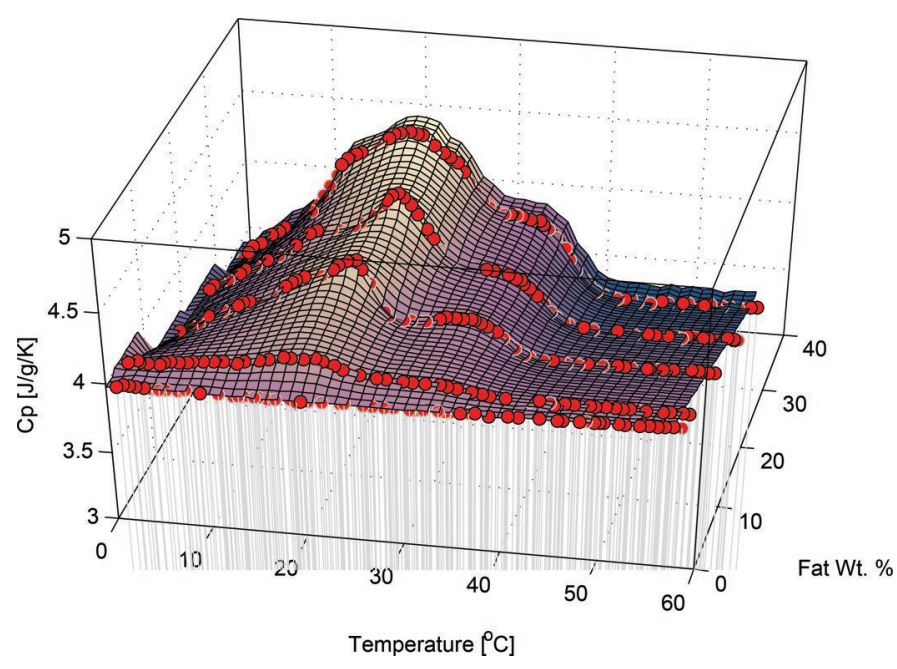

Figure 7. Model comparison of the heat capacity of milk $\left(C_{p}\right.$; $\mathrm{J} / \mathrm{g}$ per $\mathrm{K})$ as a function of temperature $\left({ }^{\circ} \mathrm{C}\right)$ and fat content $(\%$ by weight). See also Figure 8. Color version available online. monotonic, as shown in Figures 6, 7, and 8. Although heat capacity is a combination of the individual component heat capacities of the constituents, the milk fat component dominates. The influence of nonfat TS on milk heat capacity is not significant (Hu et al., 2009). Milk heat capacity data with different fat concentrations (e.g., 0.1, 3.5, 15, 25, and $35 \%$ by weight) are plotted in Figure 6. Note that the fat concentrations of whole, skim, and concentrated milk fall within this range.

Figure 6 shows the apparent heat capacity of milk for different fat contents over the temperature range of 0 to $60^{\circ} \mathrm{C}$ using data (plotted as circles) from $\mathrm{Hu}$ et al. (2009). Above $60^{\circ} \mathrm{C}$, the apparent heat capacity of milk remains the same. At temperatures below $40^{\circ} \mathrm{C}$, the heat capacity of milk fat mainly depends on temperature, and it changes significantly due to the latent heat effect. Above $40^{\circ} \mathrm{C}$, milk heat capacity does not change significantly because most solid milk fats have become liquid and there is no latent heat effect. The apparent heat capacity of milk with fat content less 


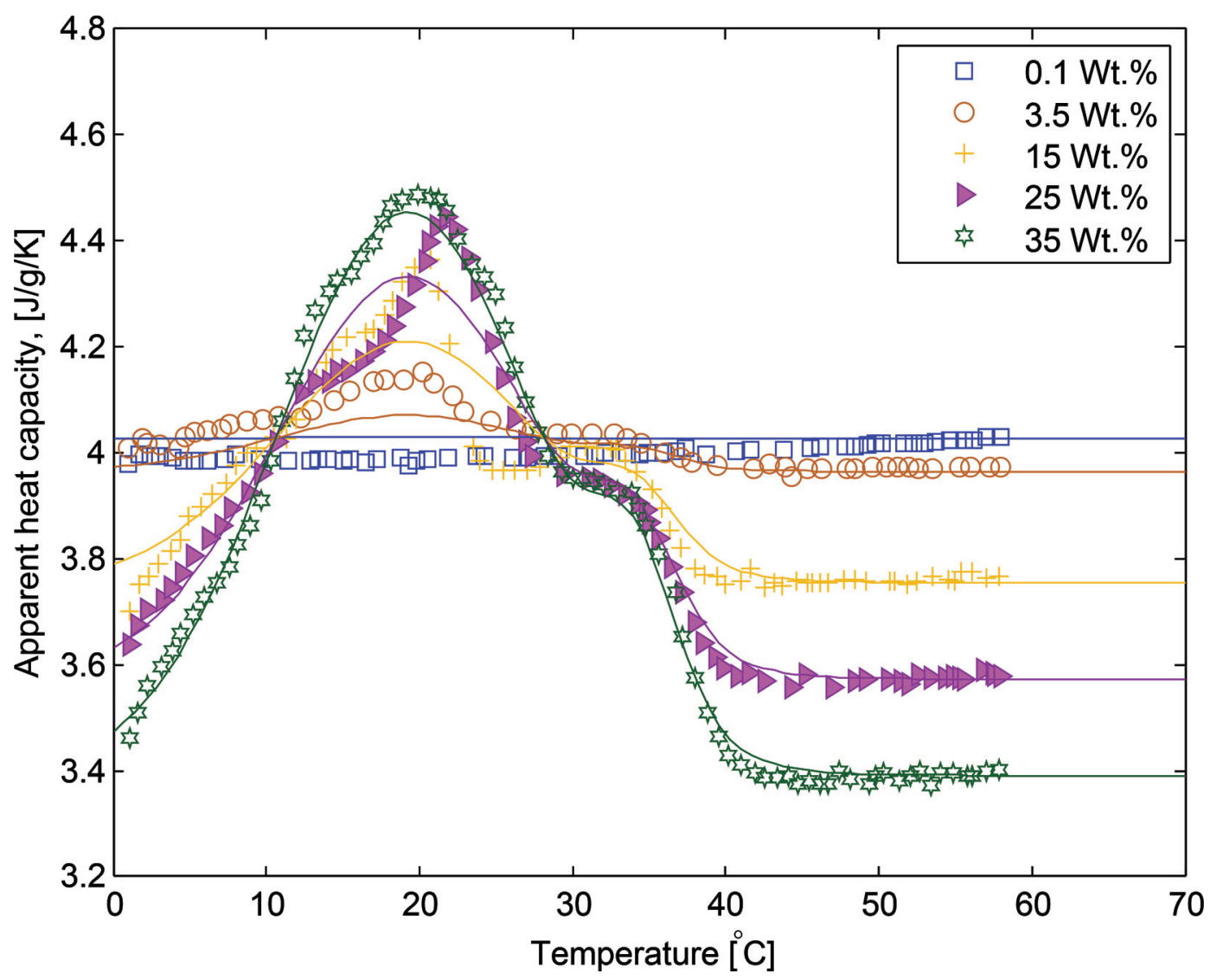

Figure 8. Model comparison using Equation [1] of the heat capacity of milk $\left(C_{p} ; \mathrm{J} / \mathrm{g}\right.$ per $\left.\mathrm{K}\right)$ as a function of temperature $\left({ }^{\circ} \mathrm{C}\right)$ and fat content $(0.1,3.5,15,25$, and $35 \%$ by weight). Color version available online.

than $3.5 \%$ (i.e., whole or skim milks) does not change significantly over the temperature range of around 4 to $75^{\circ} \mathrm{C}$. However, it varies significantly for milk with fat content above $3.5 \%$ (i.e., concentrated milk or cream) as shown in Figure 6. In other words, the behavior of the apparent milk heat capacity is linear at lower fat concentrations, $\leq 3.5 \%$ fat milk, and nonlinear at higher fat concentrations, $>3.5 \%$ fat milk. The precise value of milk heat capacity also depends on the milk fat solid:liquid ratio at a given temperature (Hu et al., 2009; McCarthy and Singh, 2009).

The simulator-embedded and newly developed "pseudo" milk databases in Zhang et al. (2015) were able to predict correct apparent milk heat capacities at lower fat concentrations. The data gathered in the present study suggested that the apparent heat capacity of milk derived from the simulator showed a close match with actual milk heat capacity for milk with a lower fat content $(\leq 3.5 \%$ fat milk). This is because the behavior of apparent milk heat capacity is linear at lower fat concentrations. Prediction of linear behavior of apparent milk heat capacity at lower fat concentration (e.g., skim or whole milk) is relatively easy for process simulators because milk behaves like a Newtonian fluid at lower fat concentrations. In contrast, at higher fat concentrations ( $>3.5 \%$ fat milk), the nonlinear or nonNewtonian fluid behavior of apparent heat capacity of milk becomes difficult to model in process simulators. Consequently, another approach is needed.

To model apparent milk heat capacity $\left(C_{p}\right)$ of milk at both high and low fat concentrations, we used the experimental data curves in Figure 6. A single model as a function of temperature and fat content was hypothesized:

$$
\begin{aligned}
& C_{p}(T, F)= \\
& p_{1}+\left\{p_{2} \exp \left[-p_{3}\left(T-p_{4}\right)^{2}\right]+p_{5} \exp \left[-p_{6}\left(T-p_{7}\right)^{2}\right]\right\} F+p_{8} F
\end{aligned}
$$

where $T$ is temperature (in ${ }^{\circ} \mathrm{C}$ ), $F$ is fat content (\%), and $p$ are regressed parameters. The regression is valid from over the ranges 4 to $75^{\circ} \mathrm{C}$ and 0 to $35 \%$ fat content. These limits are suitable for simulation of a dairy processing plant. 

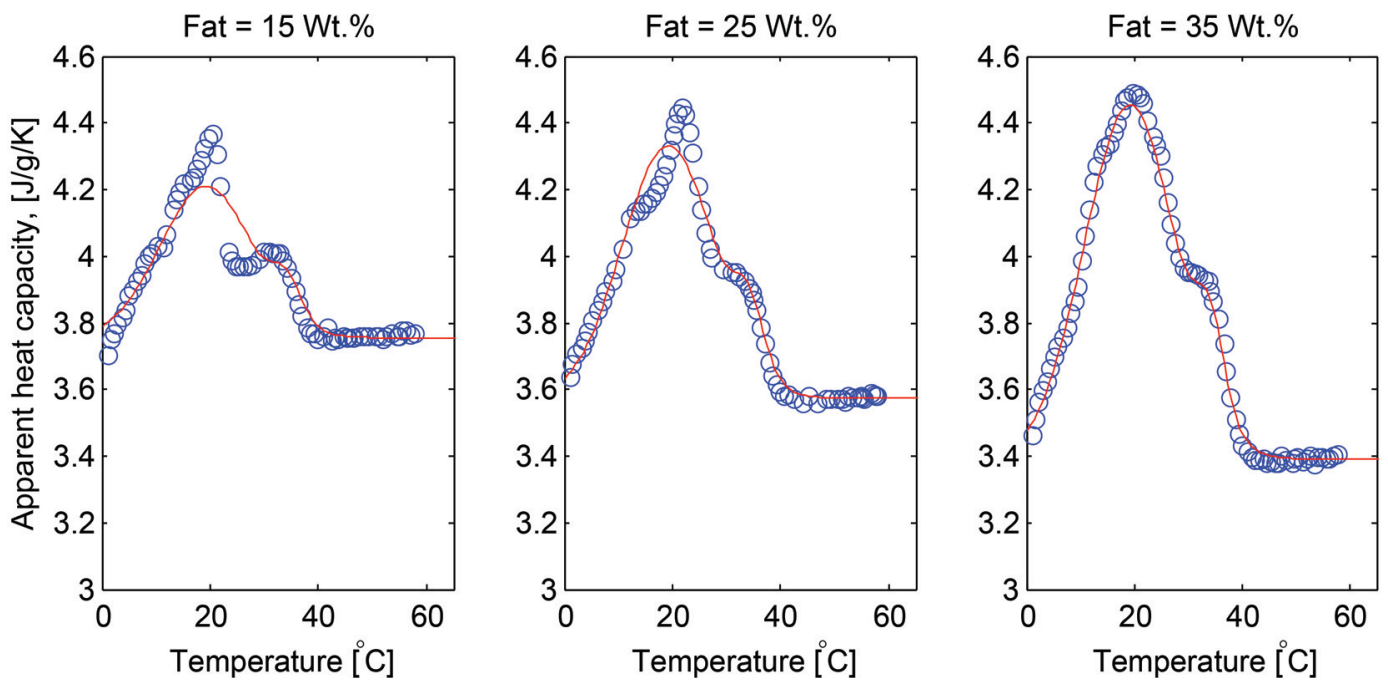

Figure 9. Separate model fit to experimental data of the apparent heat capacity of milk $(\mathrm{J} / \mathrm{g}$ per K) as a function of fat content $(15,25$, and $35 \%$ by weight). Color version available online.

This model form captures the double Gaussian peaks evident in the data, and captures the influence of increasing fat content. The regression of the 8 nonlinear parameters in Equation [1] was done via the OPTI optimization toolbox for Matlab (MathWorks, Natick, MA) from Currie and Wilson (2012).

The comparison with the experimental data adapted from $\mathrm{Hu}$ et al. (2009) is given in Figure 7 and the values of the parameters $p$ of the regressed model in Equation [1] are given in Table 5. Note that the $C p$ of milk at very low fat concentrations is essentially water and is therefore practically independent of $T$ (over the studied range) and fat content $F$ as expected. Figure 8 compares the model with the experimental data on a 2-dimensional plot. Figure 9 shows separate model fits to experimental data at higher fat concentrations (>3.5\% fat milk).

The representative Equation [1] was programmed as an external routine into the process simulator to predict complex behavior and the correct values of milk heat capacity. After programming the external routine into the process simulator, apparent heat capacity values also showed a close match (relative error $\leq 1.5 \%$ ) with actual milk heat capacity values for higher fat content milk.

The available evidence seems to suggest that recent commercial simulators can simulate all heat capacity behavior for all fat concentrations over the temperature range of 4 to $75^{\circ} \mathrm{C}$. Heat capacity behavior (mostly non-Newtonian) can be modeled by writing external programming routines to be integrated with the process simulator. Furthermore, the accuracy of heat capacity prediction may be less important, because milk temperature and milk heat requirements are connected by feedback process control loops. However, heat capacity is still important for process design.

\section{CONCLUSIONS}

In this work, the validity of the previously developed "pseudo" milk by Zhang et al. (2015) was extended by studying the effect of total milk solids and temperature on several physical properties of milk. Milk was considered a "mixture" of water and pseudo-components. The physical properties of this milk mixture were predicted using a process simulator as a function of the individual component physical properties. The simulated results were validated against experimental and literature data. The simulated results of the milk physical properties showed a reasonable match [e.g., thermal conductivity $(\leq 2 \%)$, density $(\leq 4 \%)$, viscosity $(\leq 3 \%)$, and heat capacity $(\leq 1.5 \%)$ ] with the experimental results. Consequently, modeling with such a process simulator can predict material and energy balances for dairy process-

Table 5. Regressed parameters $(p)$ in Equation $[1]^{1}$

\begin{tabular}{lcccccccc}
\hline Item & $p_{1}$ & $p_{2}$ & $p_{3}$ & $p_{4}$ & $p_{5}$ & $p_{6}$ & $p_{7}$ \\
\hline Value & 4.0283 & 0.0304 & 0.0069 & 19.2424 & 0.0071 & 0.0686 & 34.1363 \\
\hline${ }^{1} \mathrm{R}^{2}=0.9730 ; \overline{\mathrm{R}}^{2}$ (adjusted coefficient of determination) $=0.9724$. & & &
\end{tabular}


es. This work also further enables commercial process simulators for credible simulation of milk as a collection of pseudo-components for varying TS, including whole, skim, and concentrated milks over normal processing temperature ranges from 4 to $75^{\circ} \mathrm{C}$. Complicated milk viscosity behavior was also modeled in this work. The complication is due to fact that milk rheological behavior (from Newtonian to non-Newtonian) changes under the following conditions: temperature $\leq 40^{\circ} \mathrm{C}$, TS $\geq 40 \%$ (by weight), and moderate to high shear rates. Expanded fluid-based viscosity correlation and power-law models were used to model the non-Newtonian behavior of the concentrated milk. Finally, an 8-parameter simple correlation to predict heat capacity as a function of temperature and fat content was shown to be accurate over the temperature and fat ranges common in a dairy plant.

\section{ACKNOWLEDGMENTS}

The authors acknowledge the Primary Growth Partnership (PGP) program from the New Zealand Ministry of Primary Industries (New Zealand) for funding the project.

\section{REFERENCES}

Abakarov, A., and M. Nuñez. 2012. Thermal food processing optimization: Algorithms and software. J. Food Eng. 115:428-442.

Al-Nabulsi, A., R. Shaker, T. Osaili, S. Clark, F. Harte, and G. Barbosa-Cánovas. 2011. Impact of high hydrostatic pressure and heat treatments on milk gel properties: A comparative rheological study. Int. J. Food Prop. 15:613-627.

Arthur, C. J., M. T. Munir, B. R. Young, and W. Yu. 2014. Process simulation of the transport gasifier. Fuel 115:479-489.

Bon, J., G. Clemente, H. Vaquiro, and A. Mulet. 2010. Simulation and optimization of milk pasteurization processes using a general process simulator (ProSimPlus). Comput. Chem. Eng. 34:414-420.

Bradley, R., Jr. 2010. Moisture and total solids analysis. Pages 85-104 in Food Analysis. S. S. Nielsen, ed. Springer US, New York, NY.

Bylund, G. 1995. Dairy Processing Handbook. Tetra Pak Processing Systems AB, Lund, Sweden.

Byluppala, H. 2010. Process design and simulation for extraction of milk fat using liquid propane. MSc Thesis. Oklahoma State University, Stillwater.

Cheng, H., and A. Friis. 2007. Operability and flexibility of a milk production line. Food Bioprod. Process. 85:372-380.

Choi, Y., and M. Okos. 1986. Effects of temperature and composition on the thermal properties of foods. Food Eng. Process Appl. 1:93-101

Currie, J., and D. I. Wilson. 2012. Opti: Lowering the Barrier Between Open Source Optimizers and the Industrial MATLAB User. N Sahinidis and J. Pinto, ed. Savannah, GA

Dewan, R. K., A. Chudgar, R. Mead, V. A. Bloomfield, and C. V. Morr. 1974. Molecular weight and size distribution of bovine milk casein micelles. Biochim. Biophys. Acta Prot. Struct. 342:313-321.

Díaz, O. C., J. Modaresghazani, M. A. Satyro, and H. W. Yarranton. 2011. Modeling the phase behavior of heavy oil and solvent mixtures. Fluid Phase Equilib. 304:74-85.

Fernández-Martín, F. 1972a. Influence of temperature and composition on some physical properties of milk and milk concentrates. I. Heat capacity. J. Dairy Res. 1:65-73.
Fernández-Martín, F. 1972b. Influence of temperature and composition on some physical properties of milk and milk concentrates. II. Viscosity. J. Dairy Res. 1:75-82.

Fox, P. F. 2003. Advanced Dairy Chemistry: Lactose, Water, Salts and Minor Constituents. 3rd ed. Springer Science \& Business Media, New York, NY.

Gaucheron, F. 2005. The minerals of milk. Reprod. Nutr. Dev. 45:473483.

Hu, J., O. Sari, S. Eicher, and A. Rija Rakotozanakajy. 2009. Determination of specific heat of milk at different fat content between $1^{\circ} \mathrm{C}$ and $59^{\circ} \mathrm{C}$ using micro DSC. J. Food Eng. 90:395-399.

Jensen, R. G. 1995. Handbook of Milk Composition. Academic Press, San Diego, CA.

Kessler, H. G. 2002. Food and Bioprocess Engineering: Dairy Technology. Verlag A. Kessler, Munich, Germany.

Kontopidis, G., C. Holt, and L. Sawyer. 2004. Invited review: $\beta$-Lactoglobulin: Binding properties, structure, and function. J. Dairy Sci. 87:785-796.

Kumar, M., V. Sharma, D. Lal, A. Kumar, and R. Seth. 2010. A comparison of the physico-chemical properties of low-cholesterol ghee with standard ghee from cow and buffalo creams. Int. J. Dairy Technol. 63:252-255.

Lewis, M. J. 1993. Physical properties of dairy products. Pages 331380 in Modern Dairy Technology. R. K. Robinson, ed. Springer US, New York, NY.

Luyben, W. L. 2002. Plantwide Dynamic Simulators in Chemical Processing and Control. Marcel Dekker Inc., New York, NY.

Madoumier, M., C. Azzaro-Pantel, G. Tanguy, and G. Gésan-Guiziou. 2015. Modelling the properties of liquid foods for use of process flowsheeting simulators: Application to milk concentration. J. Food Eng. 164:70-89.

McCarthy, O. J., and H. Singh. 2009. Physico-chemical properties of milk. Pages 691-758 in Advanced Dairy Chemistry. P. McSweeney and P. F. Fox, ed. Springer, New York, NY.

Minim, L. A., J. S. R. Coimbra, V. P. R. Minim, and J. Telis-Romero. 2002. Influence of temperature and water and fat contents on the thermophysical properties of milk. J. Chem. Eng. Data 47:14881491.

More, G. R., and S. Prasad. 1988. Thermal conductivity of concentrated whole milk. J. Food Process Eng. 10:105-112.

Morison, K. R., J. P. Phelan, and C. G. Bloore. 2012. Viscosity and non-Newtonian behaviour of concentrated milk and cream. Int. J. Food Prop. 16:882-894.

Mühlbauer, A. L., and J. D. Raal. 1995. Computation and thermodynamic interpretation of high-pressure vapour-liquid equilibriumA review. Chem. Eng. J. Biochem. Eng. J. 60:1-29.

Munir, M., W. Yu, and B. R. Young. 2012a. Determination of plantwide control loop configuration and eco-efficiency. Pages 441-457 in Plantwide Control: Recent Developments and Applications. G. P. Rangaiah and V. Kariwala, ed. John Wiley \& Sons Ltd., Hoboken, NJ.

Munir, M. T., W. Yu, and B. R. Young. 2012b. Recycle effect on the relative exergy array. Chem. Eng. Res. Des. 90:110-118.

Munir, M. T., W. Yu, and B. R. Young. 2012c. A software algorithm/ package for control loop configuration and eco-efficiency. ISA Trans. 51:827-833.

Munir, M. T., W. Yu, and B. R. Young. 2013. Plant-wide control: Ecoefficiency and control loop configuration. ISA Trans. 52:162-169.

Ribeiro, C. P., and M. H. C. Andrade. 2003. Performance analysis of the milk concentrating system from a Brazilian milk powder plant. J. Food Process Eng. 26:181-205.

Ribeiro Jr, C. P., and M. H. Caño Andrade. 2002. A heat transfer model for the steady-state simulation of climbing-falling-film plate evaporators. J. Food Eng. 54:309-320.

Riedel, L. 1949. Thermal conductivity measurements on sugar solutions, fruit juices and milk. Dairy Sci. Technol. 93:537-549.

Seborg, D. E., T. F. Edgar, and D. A. Mellichamp. 2004. Process Dynamics and Control. John Wiley \& Sons, New York, NY.

Solanki, G., and S. S. H. Rizvi. 2001. Physico-chemical properties of skim milk retentates from microfiltration. J. Dairy Sci. 84:23812391 
Souza, G. D. 2011. Milk dryer viscosity measurement and advanced control. PhD Thesis. The University of Auckland, New Zealand.

Tajammal Munir, M., W. Yu, B. R. Young, and D. I. Wilson. 2015. The current status of process analytical technologies in the dairy industry. Trends Food Sci. Technol. 43:205-218.

Tomasula, P. M., N. Datta, W. C. F. Yee, A. J. McAloon, D. W. Nutter, F. Sampedro, and L. M. Bonnaillie. 2014. Computer simulation of energy use, greenhouse gas emissions, and costs for alternative methods of processing fluid milk. J. Dairy Sci. 97:4594-4611.

Tomasula, P. M., W. C. F. Yee, A. J. McAloon, D. W. Nutter, and L. M. Bonnaillie. 2013. Computer simulation of energy use, greenhouse gas emissions, and process economics of the fluid milk process1. J. Dairy Sci. 96:3350-3368.

Trystram, G. 2012. Modelling of food and food processes. J. Food Eng. 110:269-277.

Vélez-Ruiz, J. F., and G. V. Barbosa-Cánovas. 1998. Rheological properties of concentrated milk as a function of concentration, temperature and storage time. J. Food Eng. 35:177-190.
Virtual Materials Group Inc. 2014. VMGSim V. 8.0 User's Manual. Virtual Materials Group Inc., Calgary, AB, Canada.

Wang, Z., and S. Hirai. 2011. Modeling and estimation of rheological properties of food products for manufacturing simulations. J. Food Eng. 102:136-144.

Yarranton, H. W., and M. A. Satyro. 2009. Expanded fluid-based viscosity correlation for hydrocarbons. Ind. Eng. Chem. Res. 48:3640-3648.

Zadow, J. G. 1984. Lactose: Properties and uses. J. Dairy Sci. 67:26542679.

Zhang, Y., M. A. Dubé, D. D. McLean, and M. Kates. 2003. Biodiesel production from waste cooking oil: 1 . Process design and technological assessment. Bioresour. Technol. 89:1-16.

Zhang, Y., M. T. Munir, W. Yu, and B. R. Young. 2015. Development of hypothetical components for milk process simulation using a commercial process simulator. J. Food Eng. 121:87-93. 